\title{
Terms and usage
}

Boards of Guardians. The Poor Relief Act 1838 divided Ireland into districts or 'unions' and 'guardians' were elected by ratepayers to administer to the needs of paupers particularly in workhouses.

County is an administrative unit, of which there are thirty-two. There are four 'provinces' - Connacht, Leinster, Munster, Ulster - comprising counties.

Cove, county Cork, is used until 1849 when the town was renamed 'Queenstown' in honour of a visit from Queen Victoria and reverted to 'Cobh' in 1922. Cove/Cobh/Queenstown/Cork are used interchangeably.

Currency: $£=$ pound, $s .=$ shilling, $d$.=pence. The sterling currency system applied to Ireland and Britain during this period. In US currency, $\$=$ dollar, $c .=$ cent.

Dublin/Dublin Castle government refers to the seat of British administration in Ireland until 1922. As well as a military garrison, the chief secretary of Ireland and lord lieutenant of Ireland had offices there.

Dún Laoghaire, county Dublin, was named 'Kingstown' in 1821 in honour of a visit from George IV and reverted to Dún Laoghaire in 1921.

Exequatur: a recognition by a head of state of a foreign country's consul. HMS: His/Her Majesty's Service.

Ireland is used to describe the thirty-two county island. The Act of Union in 1800 removed Ireland's legislative independence.

Londonderry was established in 1613 and is pre-dated by the term Derry. PS: Paddle Steamer. SS: Screw Steamer.

Royal Irish Constabulary known as the Irish Constabulary until 1868, was the police force located throughout Ireland from 1822 to 1922.

Sinn Féin ('Ourselves' or 'Ourselves Alone'), a political group formed in 1905 to end the link between Ireland and Britain.

Union/Northern/Federal and Confederate/Southern are used interchangeably. 
Bernadette Whelan - 9781847793553 Downloaded from manchesterhive.com at 04/26/2023 04:40:17AM via free access 